\title{
VENOUS HEMOGASOMETRY AND BLOOD ELECTROLYTES IN MANGALARGA MARCHADOR MARES SUBMITTED TO AEROBIC TRAINING
}

\author{
Hemogasometria venosa e eletrólitos sanguíneos de éguas \\ mangalarga marchador submetidas a treinamento aeróbico
}

\author{
Tiago Resende Garcia ${ }^{1}$, Adalgiza Souza Carneiro de Rezende ${ }^{2}$, Juliano Martins Santiago ${ }^{1}$, \\ Fernando Queiroz de Almeida ${ }^{3}$, Mayara Gonçalves Fonseca ${ }^{1}$, Ana Munõz ${ }^{4}$
}

\begin{abstract}
The Mangalarga Marchador (MM) breed, valued for its marcha pace, has been excelling in functional activities such as marcha course. Considering the lack of information about sports physiology of the marcha horses, the development of training protocols and physical testing becomes essential and, in this context, the concentrations of blood gases and electrolytes provide additional information for the monitoring of metabolic changes induced by exercise. The goal of the study was to assess the hemogasometric responses and blood electrolyte concentration in MM mares during maximal effort treadmill tests carried out before and after training (trial 1) and between a maximal effort treadmill test and an incremental field test (trial 2). The trials assessed plasma lactate concentration, blood $\mathrm{pH}$, oxygen and carbon dioxide blood pressures, and blood concentrations of the ions bicarbonate, sodium $\left(\mathrm{Na}^{+}\right)$, potassium $\left(\mathrm{K}^{+}\right)$, and calcium $\left(\mathrm{Ca}^{++}\right)$. The study followed a randomized block in a split-plot design. In the first trial, the distances walked by the equines in the tests before and after training caused decrease $(\mathrm{p}<0.05)$ in $\mathrm{pH}$ and $\mathrm{Ca}^{++}$ concentration and increase in the concentrations of $\mathrm{K}^{+}$and $\mathrm{Na}^{+}$. In the second trial, the influence of the type of test and the ambient temperature caused decrease $(\mathrm{p}<0.05)$ in $\mathrm{pH}$ and increase in the concentrations of $\mathrm{K}^{+}$and $\mathrm{Ca}^{++}$. After training, MM mares had greater changes in $\mathrm{pH}$ and electrolyte concentrations.
\end{abstract}

Index terms: Equine, bicarbonate, carbon dioxide, oxygen.

\section{RESUMO}

A raça Mangalarga Marchador (MM), valorizada por apresentar como andamento a marcha, vem se destacando nas atividades funcionais, como as provas de marcha. Considerando a escassez de informações sobre a fisiologia esportiva dos equinos marchadores, a elaboração de protocolos de treinamento e de testes físicos torna-se fundamental e, nesse contexto, as concentrações dos gases e eletrólitos sanguíneos constituem informações adicionais para o monitoramento das alterações metabólicas induzidas pelo exercício. Objetivou-se avaliar as respostas hemogasométricas e a concentração sanguínea de eletrólitos de éguas MM, durante teste de esforço máximo em esteira, realizado antes e após o treinamento - ensaio 1 e entre um teste de esforço máximo em esteira e um teste de intensidade crescente a campo - ensaio 2. Foram avaliadas a concentração plasmática de lactato, o pH sanguíneo, as pressões sanguíneas de oxigênio e de dióxido de carbono, as concentrações sanguíneas dos íons bicarbonato, sódio $\left(\mathrm{Na}^{+}\right)$, potássio $\left(\mathrm{K}^{+}\right)$e cálcio $\left(\mathrm{Ca}^{++}\right)$. O delineamento foi em blocos ao acaso em esquema de parcelas subdivididas. No primeiro ensaio, as distâncias percorridas pelos equinos nos testes antes e após o treinamento resultaram em redução $(\mathrm{p}<0,05)$ do $\mathrm{pH}$ sanguíneo e na concentração de $\mathrm{Ca}^{++} \mathrm{e}$ aumento $(\mathrm{p}<0,05)$ nas concentrações de $\mathrm{K}^{+}$e $\mathrm{Na}^{+}$. No segundo ensaio, a influência do tipo de teste realizado e a temperatura ambiental resultaram em redução $(\mathrm{p}<0,05)$ do $\mathrm{pH}$ sanguíneo e aumento $(\mathrm{p}>0,05)$ nas concentrações de $\mathrm{K}^{+}$e $\mathrm{Ca}^{++}$. Após o treinamento, éguas $\mathrm{MM}$ apresentam alterações mais intensas do $\mathrm{pH}$ e das concentrações dos eletrólitos.

Termos para indexação: Equino, bicarbonato, dióxido de carbono, oxigênio.

(Received in march 12, 2013 and approved in october 1, 2013)

\section{INTRODUCTION}

In equines, high-intensity exercises impact the acid-base balance due to physicochemical and biochemical reactions associated to a greater anaerobic energy generation. The quick and intense efflux of acid equivalents from the muscle concentration causes systemic acidosis. In addition, the regulation of the acid-base balance depends on the integration of several body systems (BAYLY et al., 2006). Meanwhile, lowintensity long-duration exercises slightly raise the plasma lactate concentration and increase bicarbonate ion $\left(\mathrm{HCO}_{3}^{-}\right)$concentration during running (MEYER et al., 2010).

${ }_{1}^{1}$ Universidade Federal de Minas Gerais/UFMG - Belo Horizonte - MG - Brasil

2Universidade Federal de Minas Gerais/UFMG - Departamento de Zootecnia -Avenida Antônio Carlos - 6627 - Campus Pampulha - Cx. P. 567 - 30123 970 - Belo Horizonte - MG - Brasil - adalgizavetufmg@gmail.com

3Universidade Federal Rural do Rio de Janeiro/UFRRJ - Departamento de Medicina e Cirurgia - Seropédica - RJ - Brasil

${ }^{4}$ Universidad de Córdoba - Espanha

Ciênc. agrotec., Lavras, v. 37, n. 6, p. 559-565, nov./dez., 2013 
The increase in alveolar ventilation and the changes in intra- and extra-cellular concentrations of sodium $\left(\mathrm{Na}^{+}\right)$, potassium $\left(\mathrm{K}^{+}\right)$and chloride $\left(\mathrm{Cl}^{-}\right)$ions also act in regulating the equines' acid-base balance during exercise (HESS et al., 2006; MEYER et al., 2010). As a result of the dissociation of $\mathrm{H}_{2} \mathrm{CO}_{3}$ into $\mathrm{HCO}_{3}^{-}$and hydrogen ions $\left(\mathrm{H}^{+}\right)$within the erythrocytes, $\mathrm{Cl}^{-}$enters and $\mathrm{K}^{+}$leaves the erythrocytes. There is also greater kidney reabsorption of $\mathrm{Na}^{+}$and $\mathrm{H}^{+}$excretion for maintaining electroneutrality (MEYER et al., 2010; BARTON; LANGELAND; SNABES, 2002).

In maximal effort exercise, the transmembrane flow of $\mathrm{K}^{+}$towards the extracellular space results in acute hyperpotassemia. The plasma increase of $\mathrm{K}^{+}$is proportional to the intensity of the exercise, the active muscle mass and the plasma lactate concentration (BAYLY; KLINE, 2007). During exercise, plasma concentration of $\left(\mathrm{Ca}^{++}\right)$decreases, which, associated to the hyperpotassemia, increases the risk of neuromuscular hyperexcitability (HESS et al., 2006). $\mathrm{Na}^{+}$is the main determinant of changes in effective plasma osmolarity and, because of the intensity of the exercise, its plasma concentration increases or decreases due to intercompartmental fluid shifts, $\mathrm{H}^{+} / \mathrm{Na}^{+}$countertransporter, kidney reabsorption, and sudoresis (BARTON; LANGELAND; SNABES, 2002; COENEN, 2005; BAYLY; KLINE, 2007).

In long-duration exercise, water and electrolyte loss through sweating ranges from 10 to $15 \mathrm{~L} / \mathrm{h}$, which may lead to dehydration and be associated to low performance and clinical signs of metabolic diseases (SAMPIERI et al., 2006). According to Meyer et al. (2010), the concentration of $\mathrm{Na}^{+}, \mathrm{K}^{+}$and $\mathrm{Cl}^{-}$ions in equine sweat depends on exercise intensity, temperature, relative humidity and prior acclimatization. Shortly after starting the exercise, an equine may lose approximately $8 \%, 3 \%$ and $20 \%$ of $\mathrm{Na}^{+}, \mathrm{K}^{+}$and $\mathrm{Cl}^{-}$, respectively, through sweat (COENEN, 2005). Clinical signs associated to electrolyte loss can appear during and/ or after exercise, depending on the intensity and duration of the effort, besides environmental factors.

The goal of this study was to assess the hemogasometry responses and blood electrolyte concentration in Mangalarga Marchador (MM) mares during maximal effort treadmill tests carried out before and 42 days after training and between a maximal effort treadmill test and an incremental field test.

\section{MATERIAL AND METHODS}

The experiment was carried out in the Laboratory of Equine Performance Assessment located in the
Army's Horse Riding School, in the city of Rio de Janeiro, Brazil. 14 non-pregnant Mangalarga Marchador mares between four and nine years old weighing between 320 and $413 \mathrm{~kg}$ were used. Two trials were carried out. Trial 1 compared the hemogasometry responses and blood electrolyte concentration in Mangalarga Marchador (MM) mares during maximal effort treadmill tests carried out before and six weeks after aerobic training. Trial 2 compared the hemogasometry responses and blood electrolyte concentration in Mangalarga Marchador (MM) mares during a maximal effort treadmill test and an incremental field test, both carried out 42 days after training.

The first trial used 14 equines in a randomized block in split-plot design, where each animal represented a block, the plots were made up of the maximal effort tests in a high-performance treadmill both before and after training and the subplots were made up of the collections of baseline samples and samples immediately after exercise. The second trial used seven equines in a randomized block in split-plot design, where each animal represented a block, the plots were made up of the maximal effort tests in a high-performance treadmill and the incremental field test and the subplots were made up of the collections of baseline samples and samples immediately after exercise.

The animals were housed in individual masonry stalls with feeding troughs and drinking troughs for free access to water. The equines were fed a diet made up of Coastcross (Cynodon dactylon) hay and a commercial concentrate ${ }^{5}$. The mares were weighed weekly and, at each weighing, the daily ration was calculated as $2.5 \%$ of the living weight of each animal, which represented the dry matter intake until the next weighing. The amount of concentrate provided represented $50 \%$ of that value. These values were determined for equines in moderate work, according to the NRC (2007). The concentrate feed was split into three daily portions provided at 6 a.m., 12 p.m., and 6 p.m., while hay was split into two portions provided at 8 a.m. and 7 p.m. Mineral salt was freely available.

The mares trained for six weeks, Monday through Saturday, with the exercise on alternating days between the treadmill and the automatic horse walker. Half the animals trained on the treadmill Mondays, Wednesdays and Fridays, while the others trained on Tuesdays, Thursdays and Saturday. On the days they did not work

${ }^{5}$ Itambé ${ }^{\circledR}$ Expander Atleta Feed 
on the treadmill, the mares exercised on the walker. On Sundays, all animals rested.

The training protocol on the treadmill consisted of an initial 10-minute warm-up period, being 5 minutes walking at 1.6 meter per second $(\mathrm{m} / \mathrm{s})$ and 5 minutes marching at $3.5 \mathrm{~m} / \mathrm{s}$. Next, the treadmill was set to a 3degree slope and the mares marched at a specific individual speed for 30 minutes. This speed corresponded to $80 \%$ of the aerobic threshold speed of each animal, determined at the first maximal effort test carried out before training with the use of a spirometry mask and ranged between 3.6 and $4.4 \mathrm{~m} / \mathrm{s}$ among the animals. Cool-down was carried out for 10 minutes, being 5 minutes marching $(3.5 \mathrm{~m} / \mathrm{s})$ and 5 minutes walking $(1.6 \mathrm{~m} / \mathrm{s})$, with the treadmill flat. The exercise in the automatic walker consisted of 60 minutes walking at $1 \mathrm{~m} / \mathrm{s}$, being 30 minutes clockwise and 30 minutes counter-clockwise.

In the maximal effort treadmill tests, the mares warmed up for 10 minutes, being 5 minutes walking at 1.6 $\mathrm{m} / \mathrm{s}$ and 5 minutes marching at $3.5 \mathrm{~m} / \mathrm{s}$, with the treadmill flat. After the warm-up period, the speed was raised to 4 $\mathrm{m} / \mathrm{s}$ and the treadmill was set to a 3-degree inclination. From this point on, the speed was raised by $1 \mathrm{~m} / \mathrm{s}$ every two minutes until the animals reached fatigue, when could no longer support the speed of the treadmill. After fatigue, the mares underwent a 10-minute cool-down period, being 5 minutes marching $(3.5 \mathrm{~m} / \mathrm{s})$ and 5 minutes walking $(1.6 \mathrm{~m} / \mathrm{s})$, with the treadmill remaining at 3 degrees of inclination.

The incremental field test was carried out 48 hours after the maximal effort treadmill test. This test was performed in a $1400 \mathrm{~m}$ grassed area, measured by GPS 6 and the different animals were ridden by the same person during this test. The test consisted of a 20-minute warmup period, where the rider used walk and marcha gaits. The animals then ran the $1400 \mathrm{~m}$ track four times at different speeds, being the following gaits used: marcha (average speed of $3.5 \mathrm{~m} / \mathrm{s}$ ), extended marcha $(4.2 \mathrm{~m} / \mathrm{s}$ ), collected gallop $(5.3 \mathrm{~m} / \mathrm{s})$ and extended gallop $(8.3 \mathrm{~m} / \mathrm{s})$. At the end of each gait, the heart rate was monitored and the animal began the next stage only when the heart rate was at or below $60 \mathrm{bpm}$. At the end of the last stage, the animals underwent a recovery period, where they were conducted at walk for 20 minutes.

On the day of the maximal effort treadmill test and the incremental field test, the first blood sample (baseline) was collected at 5 o'clock by puncturing the jugular vein

${ }^{6}$ Global Positioning System with a $25 \times 0.8 \mathrm{~mm}$ needle and $1 \mathrm{~mL}$ disposable plastic syringes without anticoagulant for hemogasometry and needles for vacuum collection $\left(\mathrm{BD}^{\circledR}\right)$ and vacuum tubes with sodium fluoride (Vacutainer $\mathrm{BD}^{\circledR}$ ) in order to determine the plasma lactate concentrations. In the maximal effort treadmill test, the second blood sample was collected through the catheter and extension tube at the last 15 seconds of the final minute at gallop. In the incremental field test, the second blood sample was collected immediately after the extended gallop.

$\mathrm{O}_{2}\left(\mathrm{P}_{\mathrm{v}} \mathrm{O}_{2}\right)$ and $\mathrm{CO}_{2}\left(\mathrm{P}_{\mathrm{v}} \mathrm{CO}_{2}\right)$ blood pressures, $\mathrm{pH}$ and blood concentrations of bicarbonate $\left(\mathrm{HCO}_{3}^{-}\right)$, potassium $\left(\mathrm{K}^{+}\right)$, sodium $\left(\mathrm{Na}^{+}\right)$and calcium $\left(\mathrm{Ca}^{++}\right)$ions were measured with a portable hemogasometry device I-Stat $\left(\right.$ Roche $\left.^{\circledR}\right)$ and $\mathrm{EG}^{+}$cartridges (Roche ${ }^{\mathbb{R}}$ ). The correction of the equines' body temperature in the hemogasometry device was performed by checking rectal temperature at the same time as the collection of baseline blood samples and immediately after extended gallop in the incremental field test. In the maximal effort treadmill test, in order to correct the equines' body temperature in the hemogasometry device at the last 15 seconds of the final minute at gallop, the temperature of $40{ }^{\circ} \mathrm{C}$ was used, which corresponds to the average rectal temperature of the equines obtained immediately after the treadmill tests.

In order to determine the plasma lactate concentrations, the blood samples were centrifuged at 3000 rpm for 10 minutes so that the plasma was separated. Next, $1 \mathrm{ml}$ plasma aliquots were stored in polypropylene eppendorf tubes and stored at $-18^{\circ} \mathrm{C}$. The plasma lactate concentrations were determined using a reagent kit $\left(\mathrm{Katal}^{\circledR}\right)$ in a BTS 315 (Biosystem ${ }^{\circledR}$ ) spectrophotometer.

The results of the plasma lactate concentration did not have normal distribution and homocedasticity among the treatments and suffered a logarithmic transformation. The results were submitted to an analysis of variance and the averages were compared by Fisher's test at $5 \%$ probability with the use of the software SAEG (version 9.1).

\section{RESULTS AND DISCUSSION}

In the first trial, during the maximal effort treadmill test before training, the equines did on average 10.36 minutes of exercise, running 3600 meters. In the test performed after training, these animals did on average 12.02 minutes of exercise, running 4680 meters. There was no effect of training $(\mathrm{P}>0.05)$ on $\mathrm{O}_{2}$ and $\mathrm{CO}_{2}$ blood pressures. An increase was seen $(\mathrm{P}<0.05)$ in $\mathrm{P}_{\mathrm{v}} \mathrm{O}_{2}$ and $\mathrm{P}_{\mathrm{v}} \mathrm{CO}_{2}$ after exercise compared to the baseline values in the tests carried out before and after training (Table 1). 
Table 1 - Average hemogasometry and blood electrolyte concentration, lactate and blood pH values of equines at baseline and immediately after the maximal effort treadmill test, carried out before and after training, with their respective coefficients of variation $(\mathrm{CV})(\mathrm{n}=14)$.

\begin{tabular}{|c|c|c|c|c|c|}
\hline & \multicolumn{2}{|c|}{ Before training } & \multicolumn{2}{|c|}{ After training } & \multirow{2}{*}{$\mathrm{CV}(\%)$} \\
\hline & Baseline & After & Baseline & After & \\
\hline $\mathrm{P}_{\mathrm{v}} \mathrm{O}_{2}(\mathrm{mmHg})$ & $34.8^{\mathrm{b}}$ & $41.6^{\mathrm{a}}$ & $36.1^{\mathrm{b}}$ & $43.0^{\mathrm{a}}$ & 15.8 \\
\hline $\mathrm{P}_{\mathrm{v}} \mathrm{CO}_{2}(\mathrm{mmHg})$ & $46.2^{\mathrm{b}}$ & $53.6^{\mathrm{a}}$ & $48.2^{\mathrm{b}}$ & $52.4^{\mathrm{a}}$ & 12.7 \\
\hline $\mathrm{HCO}_{3}^{-}(\mathrm{mmol} / \mathrm{L})$ & $30.4^{\mathrm{a}}$ & $19.6^{\mathrm{b}}$ & $30.6^{\mathrm{a}}$ & $17.7^{\mathrm{b}}$ & 10.4 \\
\hline Lactate $(\mathrm{mmol} / \mathrm{L})$ & $0.97^{\mathrm{b}}$ & $15.1^{\mathrm{a}}$ & $0.97^{\mathrm{b}}$ & $16.3^{\mathrm{a}}$ & 0.5 \\
\hline $\mathrm{pH}$ & $7.43^{\mathrm{Aa}}$ & $7.18^{\mathrm{Ab}}$ & $7.41^{\mathrm{Ba}}$ & $7.15^{\mathrm{Bb}}$ & 0.9 \\
\hline $\mathrm{K}^{+}(\mathrm{mEq} / \mathrm{L})$ & $3.73^{\mathrm{Ab}}$ & $5.97^{\mathrm{Ba}}$ & $3.57^{\mathrm{Ab}}$ & $6.29^{\mathrm{Aa}}$ & 6.7 \\
\hline $\mathrm{Na}^{+}(\mathrm{mEq} / \mathrm{L})$ & $139^{\mathrm{Ab}}$ & $141^{\mathrm{Ba}}$ & $137^{\mathrm{Ab}}$ & $144^{\mathrm{Aa}}$ & 1.6 \\
\hline $\mathrm{Ca}^{++}(\mathrm{mEq} / \mathrm{L})$ & $3.31^{\mathrm{Aa}}$ & $2.91^{\mathrm{Ab}}$ & $1.70^{\mathrm{Ba}}$ & $1.49^{\mathrm{Bb}}$ & 3.7 \\
\hline
\end{tabular}

Different capital letters differ between the maximal effort tests according to Fisher's test $(\mathrm{p}<0.05)$.

Different small letters differ between the evaluation times according to Fisher's test $(p<0.05)$.

Meyer et al. (2010), assessing English Thoroughbred equines after extended effort treadmill test and Hess et al. (2006), assessing Arabian equines in incremental treadmill test at 6 and $7 \mathrm{~m} / \mathrm{s}$, found a reduction in $\mathrm{P}_{\mathrm{v}} \mathrm{CO}_{2}$ and increase in $\mathrm{P}_{\mathrm{v}} \mathrm{O}_{2}$ in venous blood. According to these authors, the reduction in $\mathrm{P}_{\mathrm{v}} \mathrm{CO}_{2}$ and increase in $\mathrm{P}_{\mathrm{v}} \mathrm{O}_{2}$ took place due to the animals hyperventilating at submaximal speeds. In the present study, the increase in $\mathrm{PvO}_{2}$ immediately after exercise compared with the baseline value was similar to the reports by Meyer et al. (2010) and Hess et al. (2006), which was expected due to the higher oxygen demand by the active muscle tissue.

On the other hand, the increase in $\mathrm{CO}_{2}$ blood pressure immediately after the exercise, compared to the baseline value, disagreed with the results reported by the aforementioned authors. The difference seen among the studies is likely due to the type of effort performed by the animals since the extended effort and gallop at 6 and $7 \mathrm{~m} /$ $s$ represent submaximal-intensity exercise. In the present study, the animals were submitted to maximal effort tests and, according to Cittar (2007), when equines are exercised at maximal speed, the locomotor-respiratory coupling in quadrupeds represent a mechanical limitation to the increase in alveolar ventilation, thus resulting in an increase in $\mathrm{P}_{\mathrm{v}} \mathrm{CO}_{2}$. Higher blood pressures were also found by Bayly et al. (2006) and Mukai et al. (2010), who attributed this increase to the higher $\mathrm{CO}_{2}$ production by the active muscle tissue.

After both tests, there was an increase in the equines' plasma lactate concentration and a reduction in blood $\mathrm{pH}$ compared to the baseline values (Table 1). Similar results were found by studies assessing endurance equines (HESS et al., 2006; SAMPIERI et al., 2006; FERRAZ et al., 2008; VIU, RAINGER; HODGSON, 2010) and race equines (EVANS et al., 1995; BAYLY et al., 2006; BRONSART; SIDES; BAYLY, 2009; MUKAI et al., 2010). According to Viu, Rainger and Hodgson (2010), the changes in blood $\mathrm{pH}$ and plasma lactate concentration in equines are more intense in high-speed exercises (racing) when compared to moderate-speed exercises (endurance).

During high-intensity exercise, the reduction in blood phosphocreatine concentration, higher anaerobic energy generation with exponential lactate accumulation and increase in $\mathrm{Na}^{+}$and $\mathrm{K}^{+}$concentration are related to the increase in plasma $\mathrm{H}^{+}$concentration (LINDINGER; WALLER, 2008). In high-intensity exercise, the reduction in venous blood $\mathrm{pH}$ is partially due to the higher $\mathrm{CO}_{2}$ production by the active muscle tissue, which within the erythrocytes is dissociated into $\mathrm{HCO}_{3}{ }_{3}^{-}$and $\mathrm{H}^{+}$(MEYER et al., 2010; HESS et al., 2006). According to Bronsart, Sides and Bayly (2009), the increase in muscle $\mathrm{H}^{+}$concentrations in intense exercises due to the higher anaerobic energy generation exceeds the buffering capacity, thus leading to a reduction in blood $\mathrm{pH}$.

In both tests, there was a decrease $(\mathrm{P}<0.05)$ in $\mathrm{HCO}_{3}^{-}$blood concentration immediately after the exercise compared to the baseline values (Table 1). In equines, part of the $\mathrm{CO}_{2}$ generated by the active muscle tissue diffuses into the erythrocytes, where it is converted into $\mathrm{HCO}_{3}{ }^{-}$and $\mathrm{H}^{+}$with the participation of carbonic anhydrase. In order 
for this reaction to continue, the $\mathrm{HCO}_{3}^{-}$produced leaves at the same time $\mathrm{Cl}^{-}$enters the erythrocytes to maintain intracellular electroneutrality (BAYLY et al., 2006; MEYER et al., 2010; COENEN, 2005; MUKAI et al., 2010). In the lungs, the opposite reaction is needed for releasing the $\mathrm{CO}_{2}$ generated by muscle activity, with $\mathrm{HCO}_{3}^{-}$entering and $\mathrm{Cl}^{-}$leaving the erythrocytes (MEYER et al., 2010). Therefore, higher $\mathrm{HCO}_{3}^{-}$concentrations are found in venous blood compared to arterial blood (BAYLY et al., 2006; CARLSON, 1995). However, according to AguileraTejero et al. (2000), although the increase in plasma $\mathrm{HCO}_{3}$ concentrations is determined by the raise in $\mathrm{CO}_{2}, \mathrm{HCO}_{3}^{-}$ concentration must decrease in order to make up for the increase in plasma lactate during effort, thus justifying the reduction in the blood concentration of $\mathrm{HCO}_{3}^{-}$found in the present study. A similar result was found by Viu Rainger and Hodgson (2010) while assessing endurance equines in a $120 \mathrm{~km}$ competition. Those authors also did not find an increase in $\mathrm{HCO}_{3}{ }^{-}$concentrations, even with the increase in $\mathrm{CO}_{2}$, and attributed that result to the increase in plasma lactate concentration.

After both tests, there was an increase $(\mathrm{P}<0.05)$ in the equine blood concentrations of $\mathrm{K}^{+}$and $\mathrm{Na}^{+}$and a decrease in $\mathrm{Ca}^{++}$. During exercise, the increase in plasma $\mathrm{H}^{+}$concentration as a result of the dissociation of $\mathrm{H}_{2} \mathrm{CO}_{3}$ into $\mathrm{HCO}_{3}{ }^{-}$and $\mathrm{H}^{+}$within the erythrocytes forces $\mathrm{K}^{+}$out of the erythrocytes so that intracellular electroneutrality is maintained, thus increasing the plasma concentration of this ion (MEYER et al., 2010). Moreover, muscle tissues contain approximately $3 / 4$ of the total $\mathrm{K}^{+}$present in the organism (COENEN, 2005) and the contraction of skeletal muscles releases $\mathrm{K}^{+}$to the extracellular space, which contributes to the increase of its concentration in the plasma (BAYLY et al., 2006; BAYLY; KLINE, 2007). According to Harris and Snow (2010), the increase in $\mathrm{K}^{+}$ concentration in equines during exercise is due to these ions exiting active muscle cells and this increase is proportional to the intensity of the exercise. The increase in lactate concentration induced by exercise is compensated by even higher increases in $\mathrm{Na}^{+}$and $\mathrm{K}^{+}$concentrations (BAYLY et al., 2006).

The increase in $\mathrm{Na}^{+}$concentration, by its turn, is related to the movement of hypotonic fluids to the extracellular space (ROSE; HODGSON, 1994; COENEN, 2005). According to Barton, Langeland and Snabes (2002), the higher $\mathrm{Na}^{+}$concentration during exercise is also associated to the maintenance of blood $\mathrm{pH}$ through kidney reabsorption of $\mathrm{Na}^{+}$and excretion of $\mathrm{H}^{+}$, acting on the maintenance of plasma hyperosmolarity and on the development of thirst. According to Meyer et al. (2010), the reduction in $\mathrm{Ca}^{++}$concentration is consistent with the hypertonic nature of equine sweat. Furthermore, the reduction in $\mathrm{Ca}^{++}$after high-intensity exercises is related to the complexation of these ions with organic and inorganic anions, the binding with albumin and the intracellular flow (FOREMAN; WALDSMITH; DALUM, 2004).

Immediately after exercise, there was a difference $(\mathrm{P}<0.05)$ between the tests, with lower blood $\mathrm{pH}$ and blood $\mathrm{Ca}^{++}$concentration and higher blood $\mathrm{K}^{+}$and $\mathrm{Na}^{+}$ concentrations in the second physical test compared to the test before the training. These differences are likely related to the greater speed and distance run by these animals after the 42 days of training.

In the second trial, which compared the maximal effort treadmill test and the incremental field test, the equines ran $4680 \mathrm{~m}$ during the maximal effort treadmill test. In the incremental field test, the equines ran $5600 \mathrm{~m}$. In the incremental field test, the rest period between each stage of the exercise for recovery and lowering of the animals' heart rate made it impossible to compare the times needed to perform the exercise between the treadmill and field tests.

Similarly to the first trial, immediately after the maximal effort treadmill test and the incremental field test, there was an increase $(\mathrm{P}<0.05)$ in $\mathrm{O}_{2}$ blood pressure, plasma lactate concentration and blood $\mathrm{K}^{+}$and $\mathrm{Na}^{+}$concentrations, while blood $\mathrm{pH}$ and $\mathrm{HCO}_{3}{ }^{-}$and $\mathrm{Ca}^{++}$blood concentrations decreased (Table 2).

A difference $(\mathrm{P}<0.05)$ was found between the treadmill and field tests for blood $\mathrm{pH}$ and blood $\mathrm{K}^{+}$and $\mathrm{Ca}^{++}$concentrations immediately after exercise (Table 2). These differences are likely related to the intervals between each stage of the incremental field test. Hence, besides the reduction in heart rate, the intervals promoted a reduction in the plasma lactate concentration due to its metabolization through oxidation in the muscle fibers and liver gluconeogenesis (MUNÕZ et al., 1999) and the influx of $\mathrm{K}^{+}$into the myocytes aiming at reestablishing acid-base balance(BAYLY et al., 2006).

Since the reduction in blood $\mathrm{pH}$ during intense exercises is related to the exponential accumulation of lactate due to the greater anaerobic energy generation and the increase in extracellular $\mathrm{K}^{+}$concentration (LINDINGER; WALLER, 2008), the lower blood $\mathrm{K}^{+}$concentrations in the incremental field test justify the higher $\mathrm{pH}$ value immediately after the incremental field test compared to the maximal effort treadmill test. 
Table 2 - Average hemogasometry and blood electrolyte concentration, lactate, and blood pH values of equines before and after the maximal effort treadmill test and the incremental field test, with their respective coefficients of variation (CV) $(n=7)$.

\begin{tabular}{lccccccc}
\hline & \multicolumn{2}{c}{ Field test } & & \multicolumn{2}{c}{ Treadmill test } & \multirow{2}{*}{ CV (\%) } \\
\cline { 2 - 3 } \cline { 5 - 6 } & Baseline & After & & Baseline & After & \\
\hline $\mathrm{P}_{\mathrm{v}} \mathrm{O}_{2}(\mathrm{mmHg})$ & $36.6^{\mathrm{b}}$ & $47.7^{\mathrm{a}}$ & & $36.6^{\mathrm{b}}$ & $45.0^{\mathrm{a}}$ & 11.3 \\
$\mathrm{P}_{\mathrm{v}} \mathrm{CO}_{2}(\mathrm{mmHg})$ & 48.6 & 43.1 & & 48.6 & 52.7 & 13.8 \\
$\mathrm{HCO}_{3}{ }^{-}(\mathrm{mmol} / \mathrm{L})$ & $30.8^{\mathrm{a}}$ & $19.8^{\mathrm{b}}$ & & $30.8^{\mathrm{a}}$ & $17.1^{\mathrm{b}}$ & 8.5 \\
$\mathrm{Lactate}(\mathrm{mmol} / \mathrm{L})$ & $1.01^{\mathrm{b}}$ & $12.22^{\mathrm{a}}$ & & $1.01^{\mathrm{b}}$ & $15.64^{\mathrm{a}}$ & 0.5 \\
$\mathrm{pH}$ & $7.41^{\mathrm{Aa}}$ & $7.28^{\mathrm{Ab}}$ & & $7.41^{\mathrm{Aa}}$ & $7.14^{\mathrm{Bb}}$ & 0.7 \\
$\mathrm{~K}^{+}(\mathrm{mEq} / \mathrm{L})$ & $3.63^{\mathrm{Ab}}$ & $5.01^{\mathrm{Ba}}$ & & $3.63^{\mathrm{Ab}}$ & $6.14^{\mathrm{Aa}}$ & 8.6 \\
$\mathrm{Na}^{+}(\mathrm{mEq} / \mathrm{L})$ & $137^{\mathrm{b}}$ & $141^{\mathrm{a}}$ & & $137^{\mathrm{b}}$ & $144^{\mathrm{a}}$ & 1.8 \\
$\mathrm{Ca}^{++}(\mathrm{mEq} / \mathrm{L})$ & $1.70^{\mathrm{Aa}}$ & $1.43^{\mathrm{Bb}}$ & & $1.70^{\mathrm{Aa}}$ & $1.50^{\mathrm{Ab}}$ & 2.4 \\
\hline
\end{tabular}

Different capital letters differ between the field test and treadmill test according to Fisher's test $(\mathrm{p}<0.05)$.

Different small letters differ between the evaluation times according to Fisher's test $(p<0.05)$.

In the field test, the average ambient temperature was $31.4^{\circ} \mathrm{C}$, while in the treadmill test, with the use of air conditioning, the ambient temperature was kept at $24{ }^{\circ} \mathrm{C}$. According to Meyer et al. (2010), the reduction in $\mathrm{Ca}^{++}$ concentration is consistent with the hypertonic nature of equine sweat and, besides exercise intensity, the concentration of this ion in equine sweat depends on the ambient temperature and relative humidity. Therefore, the lower blood $\mathrm{Ca}^{++}$ concentration found in the field test may be related to the higher ambient temperature during this test, which probably resulted in a greater loss of $\mathrm{Ca}^{++}$through sweat.

\section{CONCLUSIONS}

After 42 days of aerobic training, Mangalarga Marchador mares subjected to a maximal effort treadmill test showed more intense changes in blood $\mathrm{pH}$ and blood electrolyte concentrations related to the increase in time to fatigue.

In the incremental field test, the ambient temperature and the time between the stages of the exercise had an impact on blood $\mathrm{pH}$ and blood electrolyte concentration compared to the maximal effort treadmill test.

\section{REFERENCES}

AGUILERA-TEJERO, E. et al. Quantitative analysis of acid-base balance in show jumpers before and after exercise. Research in Veterinary Science, Rome, v.68,n.2, p.103-108, 2000.

BARTON, S.F.; LANGELAND, F.F.; SNABES, M.C. Efficacy and safety of intravenous parecoxib sodium in relieving acute postoperative pain following gynecologic laparotomy surgery. Anesthesiology, Philadelphia, v.97,n.2, p.306-314, 2002.

BAYLY, W.; KLINE, K.A. Hematología y bioquimica. In: BOFFI, F.M. Fisiologia del Ejercicio em Equinos. Buenos Aires: Inter-Médica, 2007, p.145-51.

BAYLY, W.M. et al. Changes in arterial, mixed venous and intraerythrocytic concentrations of ions supramaximally exercising horses. Equine Exercise Physiology, Cambridgeshire, v.36, n.8, p.294-297, 2006.

BRONSART, L.L.; SIDES, R.H.; BAYLY, W.M. A comparative study of interval and continuous incremental training in Thoroughbreds. Equine Comparative Exercise Physiology, Cambridgeshire, v.6, n.2,p.49-57, 2009.

CARLSON, G.P. Interrelationships between fluid, electrolyte and acid-base balance during maximal exercise. Equine Veterinary Journal, Cambridgeshire, v.27, n.18, p.261-265, 1995.

CITTAR, J.S. Sistema respiratorio. In: BOFFI, F.M. Fisiologia Del Ejercicio em Equinos. Buenos Aires: Inter-Médica, 2007, p.41-60.

COENEN, M. Exercise and stress: impact on adaptive processes involving water and electrolytes. Livestock Production Science, Amsterdam, v.92, n.2, p.131-145, 2005. 
EVANS, D.L.; RAINGER, J.E.; HODGSON, D.R. The effects of intensity and duration of training on blood lactate concentrations during and after exercise. Equine Veterinary Journal, Cambridgeshire, v.27, n.18, p.422$425,1995$.

FERRAZ, G.C. et al. Blood lactate threshold reflects glucose responses in horses submitted to incremental exercise test. Arquivo Brasileiro de Medicina

Veterinária e Zootecnia, Belo Horizonte, v.60, n.1, p.256$259,2008$.

FOREMAN, J.H.; WALDSMITH, J.K.; LALUM, R.B. Physical, acid-base and electrolyte changes in horses competing in training, preliminary and intermediate horse trials. Equine Comparative Exercise Physiology, Cambridge, v.1, n.2, p.99-105, 2004.

HARRIS, P.; SNOW, D.H. Plasma potassium and lactate concentrations in Thoroughbred horses during exercise of varying intensity. Equine Veterinary Journal, Cambridgeshire, v.24, n.3, p.220$225,2010$.

HESS, T.M. et al. Does usefulness of potassium supplementation depend on speed? Equine Exercise Physiology, Cambridgeshire, v.38, n.36, p.74-79, 2006.

LINDINGER, M.I.; WALLER, A. Muscle and blood acidbase physiology during exercise and response to training. In: HINCHCLIFF, K.W.; GEOR, R.J.; KANEPS, A.J. Equine Exercise Physiology. Philadelphia: Saunders, 2008, p.350-81.
MEYER, N.F. et al. Changes in arterial, mixed venous and intraerythrocytic ion concentrations during prolonged exercise. Equine Veterinary Journal, Cambridgeshire, v.42, n.38, p.185-190, 2010.

MUKAI, K. et al. Effects of three warm-up regimens of equal distance on $\mathrm{VO}_{2}$ kinetics during supramaximal exercise in Throughbred horses. Equine Veterinary Journal, Cambridgeshire, v.42, n.38, p.33-39, 2010.

MUÑOZ, A. et al. Cardiovascular and metabolic adaptations in horses competing in cross-country events. Journal of Veterinary Medical Science, Tokyo, v.61,n.1, p.13-20, 1999.

\section{NATIONAL RESEARCHCOUNCIL-NRC. NUTRIENTS REQUIREMENTS OF HORSES. Washington: National Academy of Science, 2007, 341p.}

ROSE, R.J.; HODGSON, D.R. An overview of performance and sports medicine. In: HODGSON, D.R.; ROSE, R.J. The athletic horses: principles and practice of equine sports medicine. Philadelphia: Saunders, 1994, p.3-25.

SAMPIERI, F. et al. Effects of oral electrolyte supplementation on endurance horses competing in 80 km rides. Equine Exercise Physiology, Cambridgeshire, v.36, p.19-26, 2006.

VIU, J. et al. Acid-base imbalances during a $120 \mathrm{~km}$ endurance race compared by traditional and simplified strong ion difference methods. Equine Veterinary Journal, Cambridgeshire, v.42, n.36, p.76-82, 2010. 